\title{
A gátizomtorna jelentősége a prevencióban
}

10.21486/recreation.2013.3.2.2

\section{Szerzők: \\ Aranyné Molnár Tímea \\ Bíró Rebeka \\ Nagy Edit dr. \\ Barnai Mária dr. \\ SZTE Egészségtudományi és Szociális Képzési Kar \\ Fizioterápiás Tanszék}

\section{BEVEZETÉS}

Minden egészséges ember számára természetes biológiai folyamat a vizelet tárolása a húgyhólyagban és annak időközönkénti kiürítése. Ennek feltétele a kismedencében elhelyezkedő szervek szabályos anatómiai helyzete és működése, a jó idegrendszeri szabályozás, valamint a medencét lezáró izmok (a szeméremcsont alsó szára és a farokcsont között kifeszülve) és a szerveket (belső nemi szervek, hólyag, húgycső, végbél) körülölelő kötőszövet épsége. Számos nemzetközi vizsgálat igazolja, hogy az izomgyengeség útján kifejlődő akaratlan vizeletvesztés, azon „szégyenbetegségek” közé tartozó föleg nőket érintő probléma, amelyek hátterében a medencealapi izmok gyengesége mutatható ki. Ha a gátizmok gyengülnek, kialakulnak a tünetek, először csak a zárófunkció sérül (vizeletcsepegés, hüvelygyengeség, szél- és széklettartási problémák, aranyér), amely már önmagában is rendkívül kellemetlen.

\section{IRODALMI ÁTTEKINTÉS}

\section{AZ INKONTINENCIÁRÓL}

Vizeletinkontinenciának nevezünk bármely húgycsövön keresztül történő akaratlan vizeletvesztést (Nemzetközi Kontinencia Társaság meghatározása, 2002). A hazai INKO Forum felmérése szerint a nők 56\%-a inkontinens panaszokkal küzd (Egészségügyi Minisztérium szakmai irányelve, 2009). A leggyakoribb fajtája a stresszinkontinencia (továbbiakban SI), mely hasüri nyomásfokozódás alkalmával jelentkező akaratlan vizeletcsepegést jelent. Osztályozhatjuk a súlyossági fokukat a kiváltó ok szerint, így lehet I fokú (köhögés, tüsszentés, szökdelés, ugrálás, nevetés, orrfújás), II fokú (lépcsőzés, leülés, felállás) és III. fokú (nyugalomban) SI (Grischke, 1996).

$A z$ anatómiai sajátosságokon és a hormonális változásokon kívül számos rizikótényező játszik szerepet a gátizom gyengülésében. Ilyenek az elhízás, székrekedés, dohányzás (ami károsítva a légzö- és érrendszert, krónikus köhögéssel járó állapotot hoz létre, ilyen módon állandó nyomásfokozódást ró a medencealapra), kismedencei műtétek, kötőszöveti gyengeség. Fontos szerepe lehet a nehéz fizikai munkának, túlzott sport- vagy szabadidő tevékenységnek, de az ülö életmódnak, a helytelen öltözködésnek (szük ruhák, övek), a helytelen ürí- tési technikáknak (vizelet/széklet tartogatása, préselése) is, valamint a stressz is növeli az inkontinencia elöfordulásának esélyét (Tápainé és mtsai, 2004; Katona és mtsai, 2006).

\section{NÖI INKONTINENCIA}

A női kötőszövet gyengébb, ráadásul életükben a meghatározott korszakokban hormonális vagy funkcionális okból áthangolódik a medencealap stabilitása (Katona, 2006). A kollagénszövet gyengül az életkor elörehaladásával, a magas intenzitású gyakorlatok erőkifejtései, hüvelyi szülések hozzájárulnak a gátizomzat gyengüléséhez (Nygaard, 1997; Sasvári és mtsai, 2008 Baessler és mtsai, 2008).

\section{PROSZTATA PROBLÉMÁK}

Az idősebb férfiaknál jelentkező prosztata problémák megoldását jelentő műtétek után is jelentős gátizom gyengülés marad vissza, amely felelős lesz a vizelési problémákért (Romics, 1996). Ezek megoldása elsősorban konzervatívmódon kezelhető (Aranyné és mtsai, 2011).

\section{DISZFUNKCIONÁLIS VIZELÉS}

A gyermekkori inkontinenciák hátterében általában szervi elégtelenség nem áll inkább a stressz és a helytelen ürítési szokások (vizelettartogatás, félig guggoló helyzet) a kiváltó okok (Mohai Juhász és mtsai, 2011; Mohai, Sándor és mtsai, 2008).

\section{DIAGNOSZTIKA}

A tünetek és az életminőség felmérése a beteg által kitöltött többféle szempontból (rizikófaktorok, tünetek) validált kérdőívek (pl. Gaudenz-féle teszt, King's Health Questionnaire, stb.) segítségével történnek. Az akaratlan vizeletvesztés mértékének, az elfolyt vizeletmennyiség pontosabb meghatározására szolgálnak a különféle pad (betét) tesztek. Az inkontinencia típusának pontos diagnosztizálása és a tünetek okának tisztázása urodinamikai vizsgálatokkal történik (Katona és mtsai, 2006).

\section{KEZELÉS}

A műtéti megoldások mellett vagy helyett, szóba jöhet a konzervatív terápia. A konzervatív kezelések az elektrostimuláció, magnetoterápia és a gátizmok erőedzése.

A medencefenék izmok harántcsíkolt izmok, így ezeket az izmokat képesek vagyunk akaratlagosan müködtetni. A medencefenéki izmok hozzávetölegesen $33 \%$-a gyors és $67 \%$-a lassú rost. A hirtelen nagy erejü izom összehúzódásért a gyors rostok felelősek, így ezen rostok fontosak lesznek a mindennapi váratlan hasüri nyomásfokozódás (pl. tüsszentés, köhögés, orrfújás, szökdelés stb.) ellensúlyozására. A lassú rostok a vizelet, szél, széklet megtartásában játszanak szerepet. Ugyanakkor a lazítás helyes elsajátítása is elengedhetetlenül szükséges a hatékony kontrakció érdekében. Hangsúlyozni 
Összefoglalás: A szerzők jelen tanulmányukban két különböző korosztálynál rávilágítanak a medencealapi izmokat gyengítő tényezőkre, amelyek okozhatnak vizeletvesztési tüneteket. Vizsgálták a fiatal nem szült nőknél jelentkező vizelettartási zavar kezelésére alkalmas gátizomtorna hatását.

A vizsgálatokban a serdülő korosztály $(\mathrm{n}=111$;

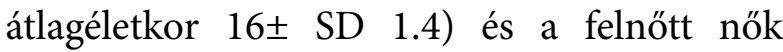
$(\mathrm{n}=311$; átlagéletkor 40 év \pm SD 10,4) vettek részt. A résztvevők kérdőíveket töltöttek ki. 14 fiatal nem szült nő ezen kívül izomerő felmérésen vettek részt, akiknél a gátizomtorna 10 hétig heti $1 \mathrm{x} 1$ óra irányított tornáztatásból és otthoni gyakorlásból állt.

Az eredmények alapján a probléma nem csak a felnőtt populációt, hanem a fiatal korosztályt is érinti. A kérdőívekből kiderült, hogy az inkontinencia rizikótényezői közül a helytelen szokások jelenléte számottevő. A tornacsoportnál a gátizmok izometriás feszítés mértékének változása szignifikánsan növekedett a tornaprogram végére (25 másodperccel átlagosan), csakúgy, mint a gátizmok dinamikus állóképességét jelző 1 perc alatti összehúzódások száma is (átlagosan 13 ismétlésszámmal).

A gátizomtorna program eredményességét támasztja alá, hogy a résztvevők a tünetek csökkenését vagy megszünését tapasztalták. Az eredmények eszközös bizonyítása további kutatási célok felállítását sürgetik.

Kulcsszavak: gátizomtorna, stresszinkontinencia, fizioterapeuta, re-educatio

kell továbbá, hogy a medencefenéki izmokat szükséges öszszehúzni minden olyan tevékenységnél, ami többletnyomást helyez a medencefenékre. A mozgásterápia célja egy reflexes mozgás megerősítése tudatos tanulással. A módszer 25-50 \% közötti átlagos javulást eredményez a vázizmok erejében 6 hónapos tréning során. Ebböl eredően a gátizom esetében ajánlatosnak tartják a minimum 15-20 hetes gyakorolást (Laycock és Haslam, 2002).

A tréning hatékonysága érdekében elengedhetetlenül szükséges az egészséget támogató életvezetési tanácsok betartása, a rizikótényezők csökkentése és a prevenció (Pikó, 2002, 2006).

\section{CÉLKITÜZÉS/HIPOTÉZIS}

A feltevésünk szerint a serdülö és a felnőtt szült és nem szült nők körében a rizikó- és protektív tényezők előfordulása gyakori és ezek jelenléte összefüggésbe hozható a tünetek előfordulási gyakoriságával. A fiatal nem szült nök körében feltételeztük a gátizomtorna hatékonyságát.

\section{ANYAG ÉS MÓDSZER RÉSZTVEVŐK}

A rizikó- és protektív tényezők vizsgálatát 2007-ben a szegedi Vedres István Kollégium középiskolásai $(n=111,14-19$ éves, átlagéletkor 16士 SD 1.4) és 2000 és 2009 között tartott gátizomtorna tanfolyamra jelentkező felnőtt szült és nem szült nők ( $n=311,20-75$ éves, átlagéletkor 40 év \pm SD 10,4) körében végeztük el. A Kollégimban elérhetőségi mintán dolgoztunk. 2009-ben a szegedi Egészségügyi Főiskolán 14 fiatal nem szült nőt (átlagéletkor 22士 SD 2,1) választottunk a tornacsoportba. A tornacsoport önkéntes jelentkezés alapján rekrutált elérhetőségi minta volt, és a mintába kerülés feltétele volt a tünetek érzékelése.

\section{KÉRDÖÍV}

Validált kérdőívek alapján az általunk összeállított kérdőívekkel felmértük a serdülő mintát a tanácsadás előtt, a felnőtt mintát a tanácsadás és a torna előtt, valamint a fiatal nem szült tornacsoportnál a tanácsadás, ill. a tréning elött és a 10 hét múlva tréning végén is. A kérdőív a tünetek (vizeletcsepegés, hüvelygyengeség, szél-, széklettartási problémák) felmérésén túl a rizikófaktorok (az életmódbeli szokások és attitűdök, illetve rizikó- és protektív tényezők ismerete) vizsgálatára is kiterjedt. A felmérést követően egészségnevelő célzattal életvezetési tanácsadást tartottunk a vizsgált személyek számára, rávilágítva a preventív lehetőségekre. A tornacsoportnál nyomon követtük az inkontinenciás panaszok súlyosságának változását a tréning során, amit a kérdőívben szereplő kiváltó ok alapján rangsoroltunk.

\section{IZOMERŐ FELMÉRÉS}

A tornacsoport egy általunk kidolgozott, számszerüsíthető (másodperc, ismétlésszám) állapotfelmérésben részesült, ahol mértük a gátizmok dinamikus állóképességét és az izometriás erőállóképesség komponenseket. A dinamikus erőállóképesség mérésére az 1 perc alatti maximális feszítések ismétlésszámát használtuk. Az izometriás izommunka vizsgálatánál mértük, hogy mennyi ideig (másodperc) képesek megtartani a maximális feszítést. Az állapotfelmérést 10 hetes mindennapos gyakorlást követően megismételtük.

\section{MOZGÁSPROGRAM}

A tornacsoportban 14 fiatal nem szült főiskolai hallgató vett részt gátizom erősítő edzésprogramunkban. A gátizomtorna 10 hétig heti $1 \times 1$ óra csoportos tréningből és napi szintű otthoni gyakorlásból állt, amelynek során hátonfekvő testhelyzetben célirányosan fejlesztettük a gátizom statikus és dinamikus komponenseit.

\section{ADATOK ELEMZÉSE}

Az állapotfelmérés során nyert adatokat a Statistica for Windows program segítségével dolgoztuk fel. Egymintás T-próbával értékeltük az izometriás és dinamikus állóképesség válto- 
zását a tréning előtt és után. Szignifikáns változást a $p \leq 0,05$ értéknél határoztuk meg. A változást százalékosan is kifejeztük. A kérdőívek adatait és a grafikonokat a Microsoft Office Excel program segítségével készítettük el.

\section{EREDMÉNYEK}

\section{RIZIKÓ ÉS PROTEKTÍV TÉNYEZÖK}

A rizikó- (szülés, klimax, testsúlytöbblet, székrekedés, vizelet tartogatása, rendszeres testedzés, stressz, nőgyógyászati és urológiai mütét) és a protektív tényezők (orvosi szűrővizsgálat, gátizomtorna tanfolyam végzése, e témakörben utána olvasás, intimtorna ismerete) előfordulási gyakoriságát a vizsgált almintákban a 1. táblázat mutatja.

\begin{tabular}{|l|c|c|}
\hline \multicolumn{1}{|c|}{ Protektív tényezők } & $\begin{array}{c}\text { Középiskolások } \\
(\mathbf{n = 1 1 1 )} \\
\text { Igen (\%) }\end{array}$ & $\begin{array}{c}\text { Felnőtt } \\
(\mathbf{n = 3 1 1}) \\
\text { Igen (\%) }\end{array}$ \\
\hline szürővizsgálat & - & 18,0 \\
\hline gátizomtorna tanfolyam elvégzése & 00,0 & 49,2 \\
\hline olvasottság a témában & 59,5 & 58,2 \\
\hline ismeri-e az intim tornát & 47,7 & 61,4 \\
\hline
\end{tabular}

\begin{tabular}{|l|c|c|}
\hline \multicolumn{1}{|c|}{ Rizikótényezök } & $\begin{array}{c}\text { Serdülö (n=111) } \\
\text { Igen (\%) }\end{array}$ & $\begin{array}{c}\text { Felnött (n=311) } \\
\text { Igen (\%) }\end{array}$ \\
\hline szülés & 00,0 & 41,2 \\
\hline klimax & 00,0 & 20,6 \\
\hline testsúlytöbblet & 14,5 & 33,4 \\
\hline székrekedés & 1,8 & 21,2 \\
\hline vizelet tartogatása & 56,8 & 43,0 \\
\hline rendszeres testedzés & - & 51,1 \\
\hline stressz & - & 75,6 \\
\hline mütét & 00,0 & 26,0 \\
\hline dohányzás & 37,0 & 27,0 \\
\hline
\end{tabular}

1.táblázat. A rizikó- és a protektív tényezők előfordulási gyakorisága a serdülő és felnőtt mintában

Összességében kitünik, hogy a felnőtt mintánál sokkal gyakoribb a rizikófaktorok előfordulása. Kivéve a dohányzást, valamint a vizelet tartogatását, melyek a serdülő mintában gyakoribbak (37\%-uk dohányzik szemben a felnőtt minta $27 \%$-ával ${ }^{1}$, illetve az adatok szerint mintegy 14\%-al magasabb a serdülö mintában a vizelettartogatás).

\section{TÜNETEK ELŐFORDULÁSA}

A serdülő és a felnőtt mintában a tünetek előfordulása az alábbiak szerint alakult (1. ábra). A felnőtt minta 45,3\%-nak van akaratlan vizeletvesztése, megdöbbenésünkre a serdülöknek már 17,4\%-a megtapasztalta az SI-t. Nagyobb arányban jelent meg a tág hüvely, miszerint a felnőtt minta $36,7 \%$-a tágnak érzi a
PELVIC FLOOR EXERCISES AND HEALTH PROMOTION

Summary: The authors presented the riskfactors at two different age groups and analyzed the effects of pelvic floor muscle training on the incontinence at young nullpara.111 teenages (average age $16 \pm$ SD 1.4), and adult women (average age $40 \pm$ SD 10,4) were participated in the study. The patients were invited to fill out a questionnaire and the muscle strenght examinations were performed. The training consisted of a 60 minutes guided exercises session per week and a continuous home exercises prepare for 10 weeks. The results of the questionnaires showed that the main risk factor is the unhealthy lifestyle. The duartion of the isometric tension of the pelvic muscles improved with an average of 25 seconds and the dynamic endurance of the pelvic muscles also ameliorated with an average 13 contractions in the pelvic muscle exercise group. The conservative therapy improve significantly the signs of incontinence. The pelvic muscle exercises resulted in strong improvements on the muscle function.

hüvelyét, a serdülő minta 46,8\%-a számol be a tág hüvelyről (a válaszoknál a levegő hüvelybe áramlásának megtapasztalását vettük alapul). A felnőtt minta 15,5\%-a szél- és széklettartási problémával küzdött, míg a serdülö minta 100\%-a mentes volt ezektöl a tünetektöl. Az aranyér a felnőtt minta 46,5\%-át érintette, és a serdülő mintánál $1,8 \%$ volt az előfordulási arány. A felnőtt mintának 6,4\%-nak (19 fö) szakorvosi vélemény alapján tudomása volt valamilyen alhasi szervsüllyedéséröl, kedvező, hogy a serdülő mintának nem volt ilyen problémája.

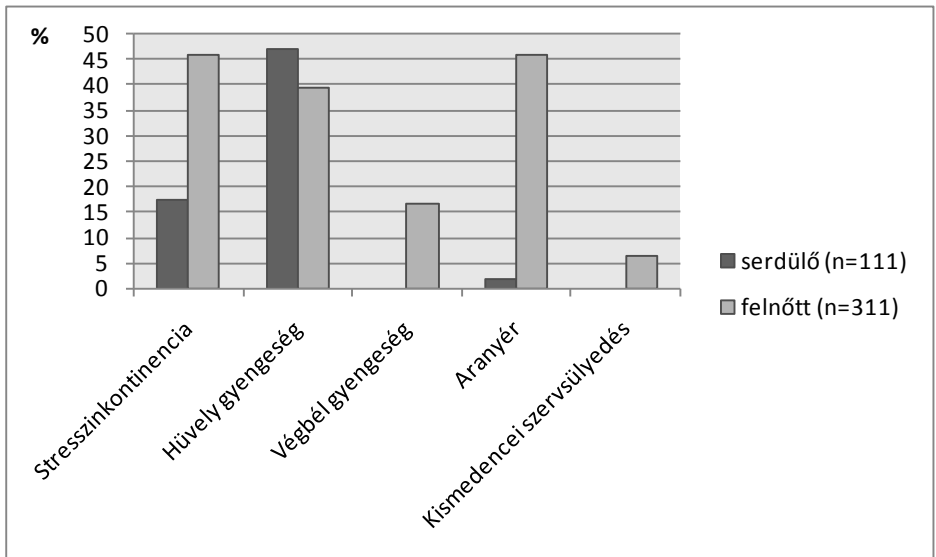

1. ábra. Tünetek előfordulása a serdülő és felnőtt mintánál

${ }^{1} \mathrm{~A}$ kapott adatok a nök körében mért dohányzás vizsgálati adatokkal harmonizálnak (Tombor és mtsai, 2010) 
A felnőtt mintában vizsgáltuk a szült $(39 \%)$ és nem szült nők (61\%) tüneteinek előfordulását. A szült nők 49\%,-a, a nem szült nők 22\%-a szenvedi el a stresszinkontinenciát. A szült nök mintában egyértelmüen magasabb a tünetek előfordulása, mint a nem szült nök mintában (2. ábra).

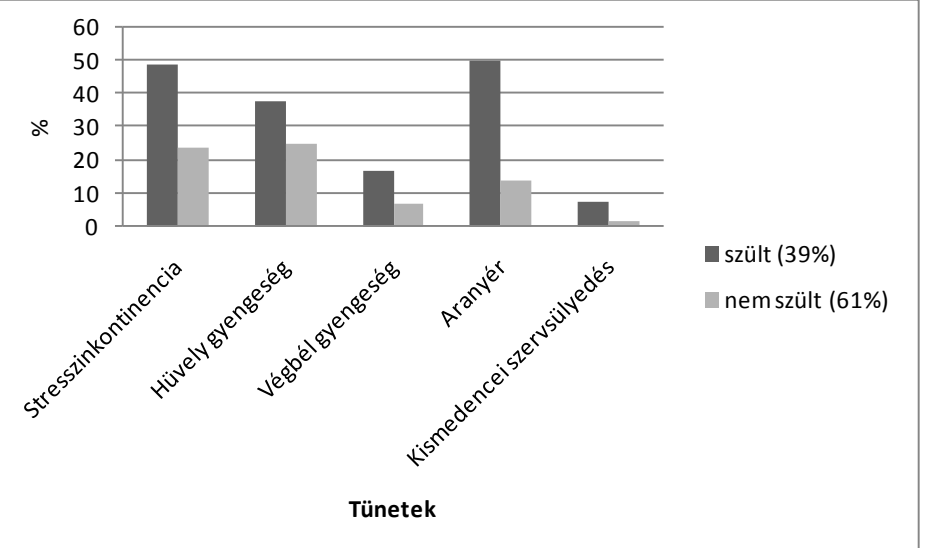

2. ábra. A szült és a nem szült minta tüneteinek elöfordulási gyakorisági jellemzői

\section{TRÉNING HATÁSA}

Mivel a tornacsoportba kifejezetten érintettség alapján kerültek be a résztvevők, közöttük a tünetek elöfordulása a tréning elött magasabb volt, mint akár a serdülő, akár a felnőtt minta átlaga, sőt, bizonyos tünetek gyakorisága a szült nők tünetgyakoriságát is meghaladta. Súlyos fokú tünet kismedencei szervsüllyedés azonban nem fordult elö. A tréning végére az SI csökkent és a hüvely-, végbélgyengeség és az aranyér teljesen megszünt (3. ábra).

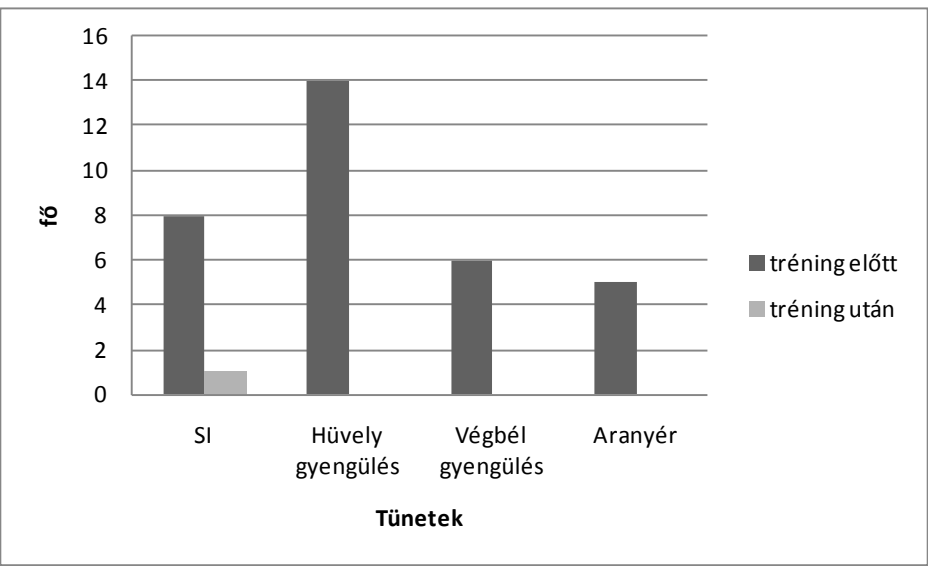

3. ábra. A tünetek változása a tréning során a tornacsoportnál

Tréning hatására a fiatal nem szült nök vizsgálatánál az enyhe fokú inkontinenciák megszüntek vagy enyhültek, a középsúlyosak enyhe fokúra mérséklődtek. 1 fő jelölte meg az inkontinencia jelenlétét, ami mégis pozitív eredmény volt, hiszen a II. fok I fokra csökkenése következett be. A kérdőívek kiértékelése során I. fokú (43\%) és II. fokú (14\%) SI-t regisztráltunk a vizeletcsepegést kiváltó ok alapján (4. ábra).

A fiatal nem szült nők almintában az izometriás állóképes-

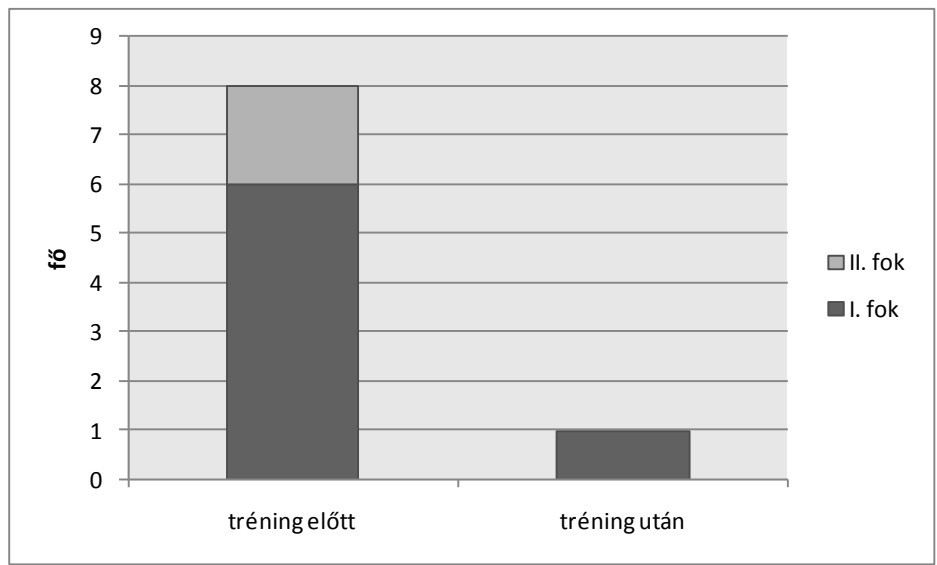

4. ábra Stresszinkontinencia fokozatainak változása a tréning végére

ség fejlődése a tréning alatt eredményesnek bizonyult, hiszen a kiindulási értékekhez (átlag 20 másodperc feszítési idő) képest a maximális feszítés megtartási ideje (átlag 45 másodperc) 6 szorosára nőtt, azaz 225\%-ot fejlődött (5. ábra).

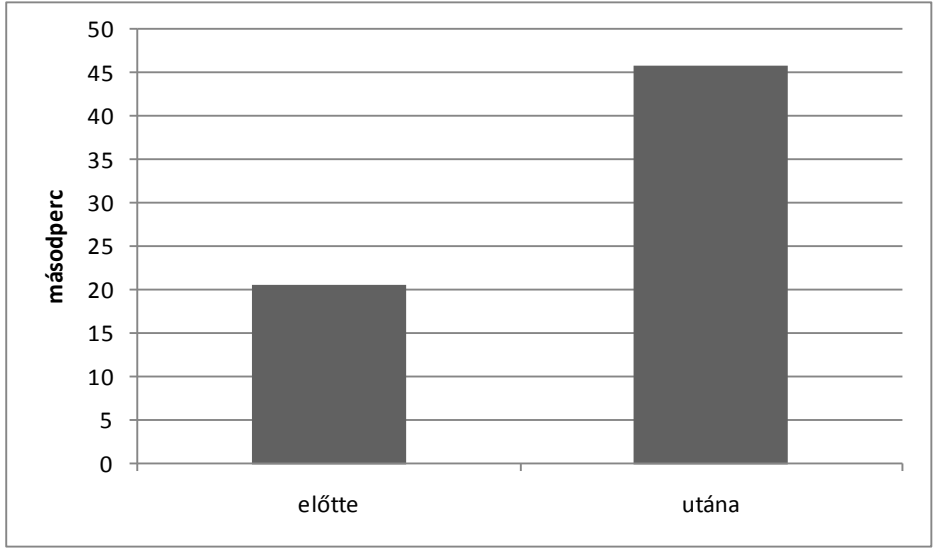

5. ábra. Izometriás kontrakió erejének változása

A dinamikus állóképesség fejlődése nem mutatott drámai emelkedést, 3 fönél a kiinduláshoz képest minimális csökkenést tapasztaltunk átlag 7 ismétlésszámmal, 11 fönél fejlődést tapasztaltunk, akik az átlag 46 ismétlésszámról átlagosan 13 ismétlésszámmal növelték percenként az összehúzás mértékét, azaz 128\%-ot fejlődött (6. ábra).

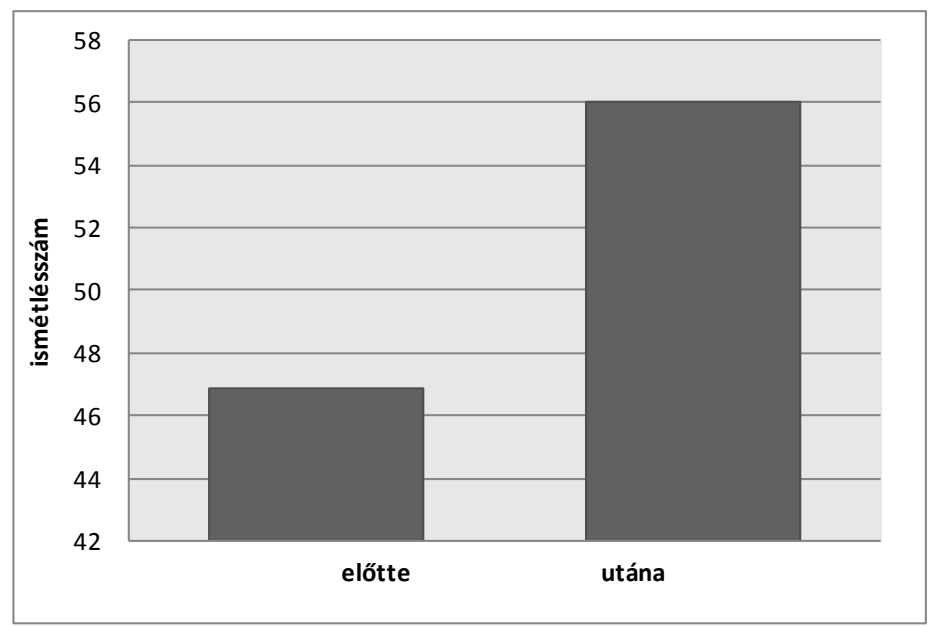

6. ábra Dinamikus állóképesség változása 


\section{MEGBESZÉLÉS}

A medencefenék izom helyes és helytelen működéséről végzett kutatások legújabb eredményeit próbáltuk bemutatni az irodalmi áttekintésben, utalva arra, hogy az inkontinencia kezelésének a kutatása folyamatos és szükséges. Ezen eredmények segítik a medencefenék fizioterápiájának fejlődését is, ami egy személyre szabott terápia felállítását teszi lehetővé.

Az adatokból kitünik, hogy az életkor elörehaladtával nő a tünetek előfordulása, illetve nem kis problémát jelent, hogy a serdülők is megtapasztalták már medencefenekét lezáró izom gyengüléses tüneteit. Katona és munkatársai (2006) is felhívják a figyelmet, hogy a prevalencia az idősbödéssel élesen növekszik. A helyzet tovább fog romlani, hiszen elöregedő társadalomban élünk.

Nygaard és munkatársai (1997) által mért 28\%-os előfordulást élsportolóknál mérték. A vizeletinkontinencia szintén előfordul azoknál is, akik nem sorolhatók az élsportolók közé, csak rendszeresen, hobbi szinten sportolnak, viszont ez a csoport rendszerint alulvizsgált, vagy egyáltalán nem is vizsgált. Az egészségügyi intézményeknek szükséges lenne felkészülni ezekre a problémákra, hogy megfelelő válaszokkal tudjanak szolgálni az őket kérdező nőknek, így a gyengüléses tünetek korábban kerülhetnének felismerésre.

Katona és mtsai (2006) szerint a túlsúlyos nők hajlamosabbak az SI-re. Tanulmányunkban elhízást csak a serdülő (1/6-a) és felnőtt (1/3-a) korosztálynál tapasztaltunk. A föiskolai hallgatóknál sem a túlsúly, sem a dohányzás nem fordult elő, ami valószínüleg sportos és egészségtudatos életmódjukkal volt összefüggésben.

Számos hazai szakirodalom által felállított rizikófaktorokat vizsgálva, elmondhatjuk, hogy előfordulási gyakoriságuk kockázatot jelentenek az inkontinencia szempontjából.

Baessler és mtsai (2008) a hüvelyi úton szült $80 \%$-nál találtak medencefenék izomkárosodást és mi is azt tapasztaltuk, hogy az általunk vizsgált felnőtt csoport azon részénél (39\%-a) akik már szültek, akiknél nagyobb százalékban fordultak elő a tünetek, mint azoknál, aki nem szültek.

Sasvári és mtsai (2008) tanulmányukban említik, hogy csak is szült nőket vizsgáltak, hiszen a nem szült nők 2-3-szor erösebb medencefenék izomerővel rendelkeznek, mint akik szültek, és izomerejük gyorsabban is növekszik. Sasvári vizsgálatában a nem szült nők izometriás állóképessége $5 x$-re nőtt, míg az általunk vizsgált nem szült nők esetében 6x-ra nőtt, ami ily módon valóban alátámasztást nyert.

Az általunk végzett vizsgálatok alapján az izometriás izommunka a megtartási funkciót javította, míg a gyors rostok fejlődése kisebb mértékű volt.

\section{KÖVETKEZTETÉS}

A vizsgált korosztályoknál a különböző rizikófaktorok jelenléte rontja az egészségi állapotot és a tünetek, a betegségek kialakulásához vezetnek. A rizikófaktorok a tünetek előfordulási gyakoriságát jelentősen növelik, így a kockázati magatartásformák helyett előtérbe kell kerülniük a preventív magatartás- formáknak. Hasznos lenne, minél fiatalabb korban elkezdeni a testi-lelki egészséggel kapcsolatos ismeretek bővítését, egészségtudatosságuk fejlesztését. A jövőben szeretnénk vizsgálni a tanácsadás hatékonyságát is, amely életmódváltást vonva maga után a tünetekre is kihathat, továbbá fokozhatja a gátizomtorna hatékonyságát.

A fokozott haspréssel járó sportolás is gyengíti a medencefeneket, és mivel a gátizom is vázizom, bár speciális helyzetü, mindenképpen hasznos, ha ennél az izomnál is fejlesztjük az erőt, az állóképességet és a gyorsaságot. A megerőltető sport komoly rizikófaktor, ezért mind az amatőr, mind a profi sportolóknál még fontosabb a tréning hangsúlyozása.

A szülés is komoly rizikótényező. Kutatásunk során a nem szült nők tornájának eredményességét vizsgáltuk, mert az ő kötőszövetjük még erősebb, így ha az erősebb, még nem sérült gátizom ilyen nagy ütemben (1-200 \%) fejlődik, akkor felmerül a kérdés, hogy a gyengébb gátizom szülés után vajon milyen ütemben fejlődik? A szült nők gátizomtornájának hatékonysági vizsgálata további kutatási célok felállítását sürgetik.

Korai hatékony gátizomtorna programot akkor tudunk öszszeállítani, ha fel tudjuk mérni a páciens medencealapi izomzatának erejét, ha vissza tudunk jelezni neki az általa elvégzett feladat helyességéröl, valamint ha pontosan tisztában vagyunk az izmok müködésével, hogy felesleges, vagy káros gyakorlatokat ne végeztessünk. Tréningünk funkcionális, egyénre szabott, specifikus legyen, s nem utolsó sorban a preventív jellegü életmódbeli tanácsokkal kell, hogy kiegészüljön.

\section{FELHASZNÁLT IRODALOM:}

» Nemzetközi Kontinencia Társaság meghatározása, 2002.

» Egészségügyi Minisztérium szakmai irányelve. (2009): A vizeletinkontinenciáról. Urológiai Szakmai Kollégium. Egészségügyi Közlöny, 2010. évi 30. szám, Budapest

» Grischke E.M.(1996): Női vizelettartási problémák, Golden Book, Budapest

" Tápainé Bajnai M. - Friedrichné Nagy A. - Kovácsics A. (2004): Gátizomtorna. B+V Lap- és Könyvkiadó Kft., Budapest „ Katona F., Prof., Dr. - Hamvas A., Dr. - Klauber A., Dr. (2006): Inkontinencia. Medicina Könyvkiadó Rt., Budapest

" Nygaard I.E. (1997): Does prolonged High-impact Activity Contribute to later Uinary Oncontinence? A Retrospective Cohort Study of Female Olympians. Obstetrics and gynecology, 90. (5.): 718-722.

"Sasvári Éva, Szüle Endre Dr., Gurmai Margit, Kenézlői Melinda (2008): A gátizomtorna hatékonyságának vizsgálata. Fizioterápia, 17. (4.) : 5-8.

» Baessler K., Schüssler B., Burgio K.L., Moore K.H., Nor- 